though both illustrations and text are too small. Particularly useful are keys to fry, parr, and adult salmons and trouts as these life history stages differ in appearance.

Each species account has a scientific name (but no date with the author), English common name, a blackand-white illustration, sections on distinguishing features, taxonomy, sexual dimorphism, hybridization, distribution with a spot map, life history, reproduction, age, growth and maturity, food habits, habitat and conservation comments.

A total of 81 species are covered, including 10 exotics. The main families of the 17 known from British Columbia are salmons, trouts and whitefishes with 23 species, minnows (20), and sculpins (8). Minor errors are inevitable in any work; e.g., Lindsey is misspelled in the dedication, Qadri as Quadri in the References, but some can be confusing; e.g., on page 498 Pomoxis nigromaculatus is said to have 5 anal spines in the sunfish identification key but most fish have 67 spines; the stickleback key separates two species by non-overlapping dorsal fin spine counts (which do, however, overlap occasionally) where in one species (Pungitius) the spines are staggered left to right, an easily seen and unique character (mentioned in Distinguishing Characters).

The book ends with an extensive Bibliography, an Appendix I (a checklist of the fishes, with no other appendices), a Glossary and an index to scientific and common names. The Glossary explains a variety of terms, even that the plural of dentary is dentaries which is fairly standard English, but gives axillae without explaining it is the plural of axilla (a knowledge of Latin is ever more dead). One obscure word is snye, defined as a dead-end side channel. This is listed in dictionaries as an Ontario word and can also mean a channel joining two rivers.

Cost is increasingly a factor in production of books and this may explain the absence of any colour plates.

\section{Owls of the World}

By J. Duncan. 2003. Key Porter Books, Toronto, Ontario. 319 pages. Hardcover, $\$ 60$.

This beautiful book actually fulfills the two roles that many natural history books aspire to but usually fall short of ... being both a detailed scientific reference and easy to read. The first two-thirds of the book cover the biology and life history of owls, stories by people who have uncovered these amazing details and the methods they used, the substantial role that owls have in mythology around the world, and threats to their survival (but also the passion and hope that people hold out for owls). The U.S. edition, published by Firefly Books, carries the apt subtitle "their lives, behaviour and survival".

The last third of the book is a detailed look at 205 species of owls: physical description, habitat, natural history, general distribution and their global conserva-
In my mind this argues for including a CD/DVD with the book to carry photographs of habitats and coloured depictions of fishes. The text can also be put on the disk, making the book searchable. I still prefer a book in the hand to a computer screen but suspect this does not apply to a younger generation. Even the $\mathrm{CD}$ in a pocket at the back of the book is a transitional stage and "books" should now appear on the internet, thereby saving trees, allowing a plethora of colour plates and other illustrations, enabling the author to receive and incorporate feedback and new data, and facilitating correction of errors of fact and of omission. A "book" on a website can be built up incrementally although some will inevitably fail to reach a completed form. Each stage allows for criticism and correction, from the initial checklist of species, the identification keys, distribution maps (allowing zoom-in for finer details than part of a book page allows), and finally text descriptions.

For those worried about vanishing websites, EM pulses and cyber trashing, a printout of say 20 copies of the digital "book" can be deposited in various libraries. This trend can be seen in some scientific works such as the "Annotated Checklists of Fishes" produced by the California Academy of Sciences which are on-line at that institution but have copies deposited in a minimum of six natural history institutions worldwide, admittedly as CDs.

This is the definitive book on this fish fauna and an essential tome for any student of the aquatic environment in British Columbia. Future versions will require multiple authors to match and improve on the experience and knowledge exhibited here by Don McPhail.

BRIAN W. COAD

Canadian Museum of Nature, P.O. Box 3443, Station D, Ottawa, Ontario K1P 6P4 Canada

tion status. Even a quick look highlights how difficult it is to study some of these species, as many do not have photographs.

Duncan brings not only his own wealth of knowledge and field experience (particularly with Great Gray Owls) to this task, but also those of a "whoo's whoo" in the world of owls, such as Robert W. Nero, Irina Menyushina, C. Stuart Houston, and Aki Higuchi. Duncan's use of anecdotes helps to de-mystify science and raises the readability level, such as when he relates being dared to taste a freshly regurgitated owl pellet in front of a crowd. He said it tasted "sweet," but his incredulous darer (R. W. Nero) bit into it and quickly spat it out, declaring that it tasted "bitter." They were both right $\ldots$ the pellet is coated with a $\mathrm{pH}$-neutral film of mucous that protects the owl's throat and mouth from the low-pH acid-soaked mass of fur and bones, which Nero had bitten into! 
As with many species, owl populations are often in trouble around the world for the usual reasons: habitat destruction, direct (vehicles, shooting, trapping) and indirect (hitting barbed wire fences) mortality, and invasive alien species such as West Nile virus. But Duncan argues that an awareness and understanding of how people have perceived owls in the past may help support efforts to conserve them today.

The one small section of the book that many people will struggle to read describes the DNA sequencing and classification of owls. It would have been more understandable if Duncan had linked this highly technical description, especially the Maximum Likelihood Tree showing owl relationships, to some of the species accounts, where it is obvious from a glance at range maps for many of the Scops Owls in the Malaysian archipelago that these species probably had a common ancestor, and allopatric speciation occurred due to island isolation.

The photos in this book are luscious, with rich colour. Today, I randomly opened it and there was a full-page picture of Verraux's Eagle Owl - the best photo that I've seen of this owl that adequately shows its pinkishpurple eyelids. I recall driving along a sandy track in Chobe National Park in Botswana when one of my companions excitedly sputtered "purple eyelids, purple eyelids," as she pointed at the bird that had caught our attention in the guidebook!

Excuse me while I read up on the Tucuman Pygmy Owl before heading off to Argentina ....

\section{CYNDI M. SMITH}

Box 5, Waterton Park, Alberta T0K 2M0 Canada

\section{Ecology, Conservation, and Status of Reptiles in Canada}

Edited by C. N. L. Seburn, and C. A. Bishop. 2007. Herpetological Conservation volume 2. Society for the Study of Amphibians and Reptiles, Salt Lake City, USA. x + 246 pages. illus., hardbound. Available from the Publications secretary of SSAR, ssar@herplit.com/U.S. \$40 plus shipping.

This book is an edited compilation of peer-reviewed contributions on several aspects of conservation and more specifically, on the ecology of the reptiles that occur in Canada. It contains chapters by many (figurative) heavyweights of Canadian herpetology, who bring combined centuries of experience to the project. The book is a very good application of accumulated biological knowledge to the question of conservation. It is also a good example of how a professional community can collaborate in a common cause.

It begins with a short introduction, then a historical review of work done on reptiles in Canada. Next are four chapters summarizing the life history of lizards, snakes, freshwater turtles, and marine turtles. Contributions on the applications of genetics to conservation, health and disease in reptile populations, and traffic mortality follow. The future of Canadian reptiles and a strategy for conservation are discussed. The book ends with an illustrated checklist of species, with the official conservation status of each. There is also a comprehensive summary of literature, both historic and recent, with few omissions.

The book succeeds in its aim of providing a summary of the biology and conservation status of Canadian reptiles. The chapters are of a consistently high calibre - a testimony to the knowledge of the authors and the thoroughness of the editors. The book is useful on more than one level - as a summary of reptile ecology in Canada and as a conservation guide; the extensive literature is also a valuable resource.

Several themes are common to the contributions. Reptiles living in Canada face two problems - the climate and humans. Because climate affects life history, reptiles are concentrated in southern Canada, where it's warmer. Unfortunately for the reptiles, humans are concentrated in the same areas. Human activities that result in habitat modification are usually in direct conflict with the best interests of reptiles.

The book makes the point that although the Canadian climate may not be ideal for reptiles, they have adapted to life here. A reader soon realizes that many, if not all, declines in reptile numbers are due to human action. For example, road mortality is a common theme in several chapters. Human alterations to the landscape can have direct effects such as habitat destruction, and also secondary effects such as increases in reptile predators like cats and raccoons. Several authors make the point that declines in reptile, especially turtle, populations can occur slowly, drawing little public attention.

Although I was familiar with much of the information presented, there were some surprises, one being the high number of marine turtles off the Atlantic and Pacific coasts. This is but one example of how much is still not known about our reptile fauna.

Quibbles are few and minor. Colour variations and aberrant scutellation in turtles should not be included among diseases and parasites; the authors themselves admit that these "..are not detrimental..." (page 149).

What is the prognosis for reptile conservation? Although knowledge of the need for conservation is high among the public, and although the number of conservation programs is high, the future still looks bleak, because of the juxtaposition of human and reptile populations. The point is made repeatedly that while atlases and monitoring programs are good, they are ultimately ineffective without concrete action; “...ecological knowledge alone will not save species when the real problems facing them are social and political." (page 47).

Ross D. MacCulloch

Department of Natural History, Royal Ontario Museum, 100 Queen's Park, Toronto, Ontario M5S 2C6 Canada; email: rossm@rom.on.ca 